Relations industrielles

Industrial Relations

\title{
Bargaining Units and Bargaining Power
}

\section{Anne Forrest}

Volume 41, numéro 4, 1986

URI : https://id.erudit.org/iderudit/050264ar

DOI : https://doi.org/10.7202/050264ar

Aller au sommaire du numéro

Éditeur(s)

Département des relations industrielles de l'Université Laval

ISSN

0034-379X (imprimé)

1703-8138 (numérique)

Découvrir la revue

Citer cet article

Forrest, A. (1986). Bargaining Units and Bargaining Power. Relations industrielles / Industrial Relations, 41(4), 840-850.

https://doi.org/10.7202/050264ar
Résumé de l'article

This paper examines how the recent amendment to the Labour Relations Actestablishing compulsory first contract arbitration in Ontario fits within the existing legal framework.
Tous droits réservés @ C Département des relations industrielles de l'Universite Laval, 1986
Ce document est protégé par la loi sur le droit d'auteur. L’utilisation des services d'Érudit (y compris la reproduction) est assujettie à sa politique d'utilisation que vous pouvez consulter en ligne.

https://apropos.erudit.org/fr/usagers/politique-dutilisation/ 


\title{
Bargaining Units and Bargaining Power
}

\author{
Anne Forrest
}

This paper examines how the recent amendment to the Labour Relations Act establishing compulsory first contract arbitration in Ontario fits within the existing legal framework.

Bargaining units ${ }^{1}$ are 'obviously of immense practical importance, not only for the immediate parties, but for the structure and performance of the collective bargaining system as a whole' the definition of the unit may dictate success in certification and 'affects the bargaining power of the union and the point of balance it creates with that of the employer' (Kidd Creek Mines Ltd., [1984] ORLB Rep 481 at 494). Everyone agrees: bargaining units are critical. Yet, when bargaining problems are analyzed, the underlying structure, and in particular the link between bargaining structure and bargaining power, is often overlooked.

That there is a chronic problem of first agreement bargaining failure in Ontario is evident. Too many unequal contests have been waged: DeVilbiss, Radio Shack, Dylex, K-Mart, Canada Trustco, Eaton's. Overall, one in seven newly certified unions failed to negotiate an agreement during the 1970 s, one in five in industries where compulsory arbitration is not imposed. And while the incidence of bargaining failure was higher when employers interfered, significantly, almost half of the unions units without first agreements encountered no petition and laid no unfair labour practice complaint $^{2}$.

The Eaton's dispute highlights the problems which unions often encounter when they confront an employer unwilling to negotiate an agreement on anything other than its own terms. The corporation was careful not to commit unfair labour practices and adhered scrupulously to the procedural requirements imposed by the duty to bargain. The union, by contrast, was critically weak: its bargaining units small, encompassing only a fraction of the firm's 35000 employees. Striking proved futile. In spite of imaginative attempts to disrupt sales and build public support, the union

* FORREST, A., Assistant Professor, University of Windsor.

1 This research was undertaken with the financial assistance of the Social Sciences and Humanities Research Council of Canada and Labour Canada. The full co-operation of the Ontario Labour Relations Board and the Ontario Ministry of Labour allowed me to compile an extensive, ten-year record of certification applications and first agreement bargaining in Ontario.

2 The data cover fiscal years 1970-71 through 1980-81. 
was never able to induce Eaton's to bargain seriously. It confidently offered an agreement with no significant concession, terms the company defended as fair and competitive but condemned as humiliating by the country's labour leaders (The Globe and Mail, Janurary 11, 1986).

Stung by many defeats, it is hardly surprising that the once doubtful union movement is now persuaded that compulsory first agreement arbitration is a necessary and appropriate method to vault unions over the critical first agreement hurdle. But the approach has short-comings. As conceived in British Columbia, first agreement arbitration was to be an extraordinary, not a universal remedy. 'We did not contemplate binding arbitration as the standard response to a breakdown in first-contract negotiations', said Weiler, then the chairperson of the B.C. Labour Relations Board. It was fashioned for the 'truly exceptional cases': 'a sharp surgical instrument for lancing those running sores in the body of industrial relations' - the 'cause célèbre' such as Fleck Manufacturing, the Port Arthur Clinic, or Artistic Woodwork (Weiler, 1980:51-3).

The recent amendment to The Labour Relations Act (Bill 65) ${ }^{3}$ in Ontario appears to cut a wider swath, providing for the settlement of first agreement disputes by arbitration 'where collective bargaining has been frustrated because of the employer's refusal to recognize the bargaining authority of the union, the uncompromising position of the respondent adopted without reasonable justification, the failure of the respondent to make reasonable efforts to conclude a collective agreement, or any other reason the board ${ }^{4}$ considers relevant'. Had grounds for intervention been limited to those associated with the duty to bargain in good faith - refusal to recognize the union and failure to make reasonable efforts to make a collective agreements - the legislation could have been said to have had in mind a Radio Shack, not an Eaton's. The Minister of Labour, however, said the measure was intended to provide broad relief, 'goes well beyond bad-faith situations and breaks new ground'. Eaton's was precisely the sort of bargaining impasse the government sought to remedy, the Premier assured the Legislature. While not proposing 'a risk-free alternative to the present system' the expectation was that 'certification should lead to a collective agreement' (Ontario, Legislative Assembly, Debates, 1985, pp. 1809; 1816-7).

This is an important departure from past policy. At present, the Ontario Labour Relations Board is reluctant to adjudicate bargaining disputes, it will not intervene in the absence of bad faith, and exercises its remedial power so as not to disturb the voluntary basis of agreements. The board's role is not that of interest arbitrator nor will it act to set right an imbalance in bargaining power. Bill 65 appears to over-ride these principles, at least in first agreement situations. 'Hard' bargaining, now acceptable, would not be a total defence. 'There are times', said the Minister, 'when intransigence in negotiations is symtomatic of a more basic resistance to collective bargaining'. While the OLRB may 'decline to grant arbitration where real progress

3 R.S.O. 1980 , c. 228 , s. 40 a.

4 The Ontario Labour Relations Board (OLRB). 
is being made', the Minister's statement suggests that employers would not be able to sustain a bargaining stance which preserves their managerial prerogative intact (Ontario, Legislative Assembly, Debates, 1985, p. 1810).

Compulsory first-agreement arbitration fits uneasily within the existing legal framework that champions voluntarism; bargaining power is unabashedly the focal point of the system. How can we justify intervention when the employer has stayed within the law? Will a first agreement, like certification, become a matter of right? Will it work; can compulsory arbitration resolve what are, in effect, recognition disputes?

\section{GOOD FAITH AND VOLUNTARISM}

Economic power is the decisive factor in collective bargaining. The law 'does not contemplate that the parties must nor that they necessarily shall conclude a collective agreement'. So long as they bargain in good faith, 'the collective agreement which they ultimately reach, or whether they conclude any collective agreement at all, must ultimately depend upon the ability and economic power which they can bring to bear in bargaining' (Fashion Craft Kitchens Inc., [1979] OLRB Rep. 967 at 970). Fruitless negotiations are no more than 'an indicator that the parties have not met the obligation' (The Journal Publishing Company of Ottawa Limited, [1977] OLRB Rep. 309 at 319); failure to agree 'may be a simple function of unreasonable demands' (Adams, 1981:154).

The duty to "bargain in good faith and make every reasonable effort to make a collective agreement' (R.S.O. 1980, c.228, s.15) is first and foremost procedural. The OLRB demands 'good bargaining practice'. Decisions which 'may precipitate strike or lock-out obviously require, as a matter of public policy, open and full discussions'; hence, the employer's failure 'to explain in any meaningful way the rationale of its final position on wages' was unacceptable (Pine Ridge District Health Unit, [1977] ORLB Rep. 65 at 71). Equally, conduct which inhibits or 'undermines the decision making capability' of the other party is unlawful (Inglis Limited, [1977] OLRB Rep. 128 at 134). It was 'patently silly to have a trade union «in the dark»' because the employer refused to provide wage and job classification data (DeVilbiss (Canada) Limited, [1976] OLRB Rep. 49 at 63). Information of this sort 'is basic to the employer's bargaining duty, particularly when the union is a newly certified bargaining agent' (Radio Shack [1979] OLRB Rep. 1220 at 1225). Full and frank discussion was similarly precluded when an employer asserted its own interpretation of the anti-inflation guidelines and refused to discuss any other (Canadian Industries Limited, [1976] OLRB Rep. 199). And, by extension, it was unlawful for a council of unions to insist upon resolving a jurisdictional dispute before proceeding to other issues: 'the duty to discuss fully does not permit a party to discuss the issues of its choice to the exclusion of all others' (The Journal Publishing Company of Ottawa Limited, [1977] OLRB Rep. 309 at 320).

Misrepresentation is the 'antithesis of good faith' and alien to the collective bargaining process (Inglis Limited, supra at 135); hence, reneging on a tentative agreement constituted bad faith (Pine Ridge District Health 
Unit, supra) as did the last minute tabling of sixteen new demands (Graphic Centre (Ontario) Inc., [1976] OLRB Rep. 221). For the same reason, an employer must take the initiative to inform the union of 'those decisions already made which may have a major impact on the bargaining unit' and must 'respond honestly' when questioned, but is not obligated 'to reveal on his own initiative plans which have not become at least de facto decisions' (Westinghouse Canada Limited, [1980] OLRB Rep. 577 at 598; 599).

The substantive element of the duty to bargain is less readily described. Good faith in this sense is the 'absence of the intention to destroy the union's bargaining rights' (Adell, 1980:19); thus, conduct which undermines the union's status as exclusive bargaining agent is unacceptable. It was unlawful for an employer to refuse to bargain though it honestly believed the union had lost its claim to majority support (Bentley's Sporting Goods 59 CLLC, para. 18,129 (OLRB)). Similarly, impugning the union's credibility by publicly disparaging its bargaining proposals was a breach of the duty, (A.N. Shaw Restoration Ltd. et al., [1978] OLRB Rep. 393) as was an attempt to interfere with the right of unions 'to shape their own bargaining structure, and choose their own spokesmen' (The Journal Publishing Company of Ottawa Limited, supra at 321). The employer must bargain with the union and not directly with the employees (Sack and Mitchell, 1985:454).

Bargaining demands which suggest an employer's unwillingness to recognize the union are also suspect. An of fer of lower wages for unionized workers was unacceptable because of the 'implicit promise of continued preferential treatment to its non-unionized employees'. It was 'plainly unlawful' for an employer 'to punish a group of employees because they have chosen union representation or to reward another group because they have not' (Irwin Toy Limited, [1983] OLRB Rep. 1064 at 1072; 1067). 'Patently unreasonable' proposals were unlawful: demands that lacked 'any semblance of business justification' suggested the 'desire to embarrass the union and encourage its abandonment by the employees'. Radio Shack's offer would have left the workers with fewer rights than they had before the arrival of the union, the union alleged and the OLRB concluded that there was 'little doubt that the employer's positions on wages, transfer, union security and rules of conduct cut to the very heart of a collective agreement' and were advanced 'for the purpose of provoking the Complainant into an untenable strike' (Radio Shack, supra at 1243:1249).

Radio Shack was flagrant in its disregard for its workers' rights, but what about the employer 'who has a fixed resolve to avoid an agreement but who is prepared to go through all of the bargaining motions, including the full, free and rational discussions of positions' (Armstrong, 1976:35)? Divorced from anti-union behaviour, bad faith is an elusive concept. 'If an employer is 'careful to refrain from any other conduct which is inconsistent with a desire to enter into an agreement, no finding of failing to bargain in good faith will be possible', Bendel concluded (1980:30). Though unlawful, surface bargaining - 'going through the motions' - is readily disguised as hard bargaining, so difficult to prove. 
In principle, hard bargaining is lawful. Even though one party has 'overwhelming strength', 'raw bargaining power' exercised in good faith 'does not offend the bargaining duty' (Radio Shack, supra at 1242). Proposals which are unacceptable, or even 'predictably unacceptable', are not necessarily a breach of the good faith obligation. Neither party is required to make concessions (The Daily Times, [1978] OLRB Rep. 604 at 610). Thus, an employer that protests its preparedness to sign an agreement, though only on its own terms, is acting within the law ( $\mathrm{CCH}$ Canadian Limited, [1974] OLRB Rep. 375).

Eaton's was exceedingly careful to comply with the letter of the law: certification was free of detectable unfair practices, the union was frequently acknowledged as the bargaining agent, requests for information were satisfied, there was no attempt to interfere with the composition of the union's negotiating committees, and so on. At the same time, the talks were fruitless: long, drawn-out and repetitive. Despite its admission that higher wages and benefits 'would simply encourage employees in our other stores to organize', the board concluded that Eaton's bargaining stance was hard, but lawful. To ensure an agreement contains favourable terms, 'terms which will retain for management most of the flexibility it currently enjoys and which will not result in any increase in operating costs', was a legitimate bargaining objective (T. Eaton Company Limited, [1985] OLRB Rep. 491 at 510:504) $)^{5}$.

Though lawful, 'hard' bargaining may be all that is needed to escape a union. An employer that scrupulously avoids aggressive behaviour may nevertheless be relying on its overwhelming bargaining strength to evade unionization; a tough stance 'may well have a secondary (or not so secondary) purpose of disillusioning the employees about what a union can do for them' (Adell, 1980:19). What can be said of the employer that seeks to retain its managerial prerogative intact, demands complete control over discipline, rejects the principle of seniority, and offers a wage increase 'so small as to be tailor-made for union and employee rejection' (Goldcraft Printers, [1980] OLRB Rep. 448 at 449)? Certainly not that it accepts the principle of collective bargaining: 'No employer ever sought to reserve complete unilateral control unless he expected the negotiations to fail'. So long as there are unions 'weak enough to be talked to death, there will be employers who are tempted to engage in the forms of collective bargaining without substance' (Cox, 1958:1425; 1413).

\section{BARGAINING UNITS AND BARGAINING POWER}

Newly certified bargaining units are small in Ontario, averaging 46 employees. Only one unit in ten is larger than 100 (Annual Report 1984-85, p. 99) ${ }^{6}$. Units of this size, powerless almost by definition, are the product of the Ontario Board's preference for a highly fragmented structure of

5 Eaton's demand to write into the collective agreement a clause prohibiting all union activity on company property was found to be a violation of the act.

6 The data are for the non-construction industries only. 
recognition. Each establishment is considered a natural bargaining constituency: the 'single-employer, single-location, single-plant unit' is the cornesrstone of OLRB policy (Bromke, 1961:80). Within the establishment, office workers are separated from production and part-time workers from full-time.

Multi-establishment units are rare. Despite common skills, work, wages, and conditions ${ }^{7}$, the union's request for multi-plant recognition at Magna International was denied. The workers' community of interest at the three closely related sites was held to be 'more local': the absence of transfers between locations meant that employees 'would not see work at the other plants as part of any promotional opportunity and may well feel threatened by anything more than plant-wide collective agreement administration' (Magna International Inc., [1981] OLRB Rep. 1260 at 1264). Similarly, the employees of Adams Furniture were divided into three bargaining units where one had been sought - there was 'simply no evidence to establish a community of interest among the employees in a regional bargaining unit of the size proposed by the applicant' (Adams Furniture Co. Limited, [1975] OLRB Rep. 491 at 494).

Retailing was the one notable exception to the single-establishment policy. Because terms and conditions of employment were standardized, 'the interests of employees throughout a group of stores can be said to be essentially similar' and it would not be 'conducive to sound collective bargaining for a series of bargaining units to be established in respect of groups of employees performing similar tasks and having similar interests' (Goodyear Service Stores, 65 CLLC, para. 16,018). Until the mid-1970s, the standard unit in retail and service stores was all locations within the municipality (Sack and Mitchell, 1985:144-5). However, the realities of organizing fast food restaurants, stores, and trust companies has shaken the board's confidence in this approach. The multi-establishment unit was itself an obstacle to organizing, so abandoned. Recognizing the 'right to selforganization' as a 'primary theme' of the act (Ponderosa Steak House, [1975] OLRB Rep. 9 at 10) the board has said it will 'lean towards the bargaining structure which best facilitates organization' in industries where 'collective bargaining has not taken a foothold' (K Mart Canada Limited, [1981] OLRB Rep. 1250 at 1258). Single-establishment certification is now common ${ }^{8}$.

The separation of office employees is an equally well-entrenched policy. To the Ontario Board 'it is readily apparent why plant units, or office and sales units are appropriate as a subdivision of an employee unit' (The Board of Education for the City of Toronto, [1970] OLRB Rep. 430 at 436). Initially, the practice was more flexible and permitted combined units if the workers 'clearly express a preference for organization along those lines' (Corbin Lock Case, [1944] DLS 7-1109). But rigidity soon followed:

7 These are factors the board considers important as measures of workers' community of interest. See Usarco Ltd., [1967] OLRB Rep. 527.

8 The conundrum of the service industries continues to press the board to experiment. In the recent National Trust decision (File No. 0414-85-R, February 28, 1986, as yet unreported) a unit of seven, unrelated Toronto branches was created. 
'save in the most exceptional circumstances' office workers ought to be placed in a bargaining unit 'separate and apart from other employees' $(H$. Gray Ltd., 55 CLLC, para. 18.011). And this remains the firm policy.

Likewise, separate units for part-time workers (and students) reflects the view that these workers generally do not share a community of interest with full-time employees'. The former are "primarily concerned with maintaining a convenient work schedule which permits them to accommodate the other important aspects of their lives with their work and with obtaining short-term immediate improvements in remuneration rather than with obtaining life insurance, pension, disability, and other benefit plans; extensive seniority clauses; and other long-term benefits (Toronto Airport Hilton, [1980] ORLB Rep. 1330 at 1331). Accordingly, part-time workers will be segregated at the request of either party (Sack and Levinson, 1973:70).

The OLRB's preference for narrow units ensures homogeneity. It worries that bargaining interests of disparate groups may be impossible to reconcile in broader units or, if too much attention is paid to minority groups, it may be 'more difficult for a union to formulate a coherent package of proposals or make necessary concessions' (Kidd Creek Mines $L t d$., supra at 495). 'If the bargaining agent is not able to represent effectively all groups within the unit, there is a good chance that this will affect the viability of the collective bargaining relationship itself' (Adams Furniture Co. Limited, supra at 493). But the gulf between establishments, between blue - and white-collar or between full - and part-time employees is neither so wide nor so unbridgeable as the policy suggests. Common and sectional interests are intertwined. The board itself has noted that 'different communities of interest will exist at one and the same time among several different groupings of employees' (Canada Trustco Mortgage Company, [1977] OLRB Rep. 330 at 333).

The OLRB's standard units entrench an artificially narrow conception of worker's common interests. A common employer creates a community of interest. Wages are a powerful unifying force. From the workers' point of view, the elimination of wage differentials between locations or between full - and part-time workers may be more than just equitable, it is a practical means of combatting employer whipsawing. Sources of tension within a work force are many and not limited to those institutionalized by the board's practices. Office workers may have demands unique to their situation but so do women, immigrant, skilled, and senior groups, though none is recognized as a distinguishable bargaining constituency. When interests collide, the responsability for sorting out the competing demands and priorities belongs to the union, not the OLRB. Tough decision-making is the essence of collective bargaining. In Weiler's words, 'Collective bargaining is intrinsically valuable as an experience in self-government'. Organized workers 'take their destiny into their own hands, deciding what kind of working conditions they want': 'choices must be made, priorities determined, [and] compromises struck between the contrasting interests of different groups inside the bargaining unit' (Weiler, 1980:32-3).

9 Other boards are not committed to this practice. The Canada Board, for example, distinguishes between regular and casual, not full - and part-time, employment (DORSEY, 1983:130). 
Of course, narrowly described units do not prohibit broader-based bargaining. The parties are free to alter the composition of the unit; however, neither may insist on a broader structure. Any demand aimed at altering the scope of the bargaining unit 'must be removed from the bargaining table once a strike or lock-out if imminent or in progress' (Toronto Star Newspapers Limited, [1979] OLRB Rep. 451 at 455). Accordingly, it was unlawful for the union to insist on preserving national bargaining with Burns Meats. Representation rights are defined by the bargaining unit, the board ruled; hence, it was inconsistent with the scheme of the Act to insist on bargaining beyond the confines of those rights. The demand itself was not illegal: bargaining structure may be 'raised and discussed' but it 'cannot legally be pressed to impasse' (Burns Meats Ltd., [1984] OLRB Rep. 1049 at 1058). In the absence of mutual agreement, therefore, it is the OLRB's standard units which determine bargaining structure. Accordingly Eaton's was 'legally entitled to bargain separate collective agreements for each store', indeed, for each full - and part-time unit. Rejecting broader-based bargaining, Eaton's chief negotiator explained that a 'master agreement had created several difficulties for management' at Canada Packers, his previous employer (T. Eaton Company Limited, supra at 502; 493).

Unit-by-unit bargaining may leave the union weak and vulnerable, and when it complains of the employer's bad faith, the OLRB is apt to conclude that the obstacle is hard bargaining. The board will not intervene; it will not 'redress any imbalance of bargaining power that may exist between the parties' (Pine Ridge District Health Unit, supra at 7). The law 'provides for the use of economic sanction and not interest arbitration as the ultimate means of determining contractual terms' (The Daily Times, supra at 609); the strike 'determines which side will find it more painful to disagree, which party will be forced to make the major moves toward compromise' (Weiler, 1980:49).

\section{FIRST AGREEMENT ARBITRATION}

Compulsory first-agreement arbitration is intended to break this legal impasse. Where the overwhelming power of one party has stymied bargaining the OLRB is empowered to intervene.

A free collective bargaining will not be imperilled, the government has said. Nevertheless, employers fear they will lose control of their own affairs; that an agreement will be imposed when management adopts a tough stance 'motivated by real and legitimate concerns' (The Globe and Mail, January 2, 1986). Bargaining power will be pushed aside. Not only will arbitrators impose terms and conditions that are unwanted, from the employer's perspective they would be unwarranted. To get the agreement it wants, a union 'without the bargaining clout... can simply ask the province to arbitrate and a binding contract will be imposed' (The Globe and Mail, January 2,1986 ). In a voluntary system, the terms of agreements reflect the balance of power: the strong get more, the weak less. To jettison this principle is to disrupt the foundation of collective bargaining. Where will it all end?

The union movement, by contrast, is willing to bend its voluntarist principles for greater equity. But will it work? Can first-agreement arbitration resolve modern-pay recognition disputes? 
In British Columbia, arbitrated agreements failed to 'lay the foundations for a more mature and enduring relationship'. Most unions did not negotiate second agreements; the 'trial marriages' frequently ended in separation (Weiler, 1980:53-4). More hopeful is the experience of the Manitoba Board. Agreements were renewed in four of seven cases, although at least one of the unions was subsequently decertified (Korpesho, 1986:4).

Interest arbitration does not bolster the bargaining power of weak unions. Even when access is generous, as in Manitoba, the fix is unlikely to be more than temporary when the real problem is an imbalance of power. Just as certification at times does little more than postpone recognition. disputes, so too compulsory arbitration. Unions too weak to win acceptable agreements in the first round may succumb to hard bargaining during the second.

Bargaining power is often discussed as though it were a naturally occurring, fixed entity, unaffected by public policy. In fact, however, the law does much to shape the power of the parties. The OLRB's small units fragment the work force and make sanctions less effective. Lawful sympathic action is almost impossible; attempts by other groups to act in support are quickly met by a finding of illegal strike ${ }^{10}$. Unions are also shackled by the broad definition of strikes in Ontario, the illegality of untimely stoppages, and the criminality of picketing which interferes with access and egress. Employers, by contrast, are structured on a broad basis: the productive and financial capacity of the entire firm can be utilized to reinforce its bargaining position at any establishment. Untimely lock-outs are unlawful, of course, but employers are free to replace striking or locked out employees and to shift production to other locations.

\section{FLEXIBLE BARGAINING UNITS}

If unions are to be an effective countervailing power, they must be allowed to organize on the same basis as employers. While small units encourage organizing, the realities of bargaining suggest that more extensive units may be necessary to transform the promise of certification into a collective bargaining relationship.

Broader-based units are note precluded by the Act. Legally, a bargaining unit is simply 'a unit of employees appropriate for collective bargaining' and may be 'an employer unit or a plant unit or a subdivision of either of them' (R.S.O. 1980, c. 228, s. 1 (1) (b)). But while the board is flexible in theory, it has been less accommodating in practice. Its standard units are ' $a$ kind of norm' injecting 'an element of certainty into the certification process' and ensuring 'some uniformity in collective bargaining across an industry' (University of Windsor, [1983] OLRB Rep. 478 at 479) - even though the act requires only that units be appropriate, not 'more' or 'most' appropriate (The Board of Eduction for the City of Toronto, supra).

10 An overtime ban to enhance the union's bargaining position at another location was an illegal strike (Canada Packers Inc. [1983] OLRB Rep. 1405) as was a refusal to cross a picket line (Toronto Transit Commission, [1984] OLRB Rep. 1781). 
The solution may be to allow workers to amalgamate their units. Since employers are free to choose the structure which suits them best, employees should have an equivalent right. Alternatively, to bring the process under the act, unions could apply to the OLRB for a vote to determine workers' preferences. In fact, the board is already permitted to conduct a vote 'for the purpose of ascertaining the wishes of the employees as to the appropriateness of the unit' (R.S.O. 1980, c. 228 , s.6(1)), but as the board believes it has no authority to restructure existing units ${ }^{11}$ an amendment would seem to be necessary.

Restructuring would be of particular importance in the unorganized sectors of economy. In the retailing, restaurant, finance and insurance industries small establishments are predominant. Each outlet supplies similar products and services; no unit alone has the ability to impose a serious financial penalty on an employer. Because sanctions are relatively ineffective, location-by-location bargaining can be fatally weak and a bid for recognition easily rebuffed. Certification may be granted, but the workers lack the economic power necessary to force a reluctant employer to bargain seriously. To discourage unionization, large firms are willing and able to spread any losses over the whole business. Broader-based union structures would partially redress this structural imbalance.

Restructuring would eliminate the unit-by-unit struggle for recognition. Instead of an isolated demand for recognition, the employer would be confronted by a co-ordinated effort. Certification would still be no more than a 'legal licence to bargain' (Weiler, 1980:48) and bargaining power would remain the decisive factor. Not all unions would negotiate agreements; nor would workers win all the changes they desired. Once an agreement was reached, however, newly certified units would be covered by its terms if they chose to affiliate with the established group. The agreement would be binding as negotiated so that if some issue were outstanding - if, for example, the parties could not agree on a wage rate for a newly organized unit of part-time employees - it would be deferred to the next negotiating round ${ }^{12}$.

Whether a broader-based bargaining structure would have helped the Eaton's workers is uncertain. Though they were divided into fourteen units, they struck as one group; thus, the collective agreement reflected the workers' collective power. It is conceivable, however, that the union's strategy would have been different. Knowing it could build a more extensive negotiating unit overtime, the union might have accepted Eaton's terms in order to concentrate on organizing while enthusiasm was high. And even though the agreement was disappointing, the members might have appreciated the wisdom of a longer-term strategy over the risks of an immediate confrontation. If, for the sake of argument, a dozen more stores had been brought under the contract before it expired, the union would have been better placed to negotiate more satisfactory terms.

11 See City of Toronto Non-Profit Housing Corporation [1982] OLRB Rep. 280.

12 For the practice of the Canada Labour Relations Board when amalgamating units, see DORSEY, 1983, 181-3. 
Today, there is rarely a dramatic last stand on the picket line and bloody clashes with the police are infrequent; yet, many workers are unable to exercise the rights conferred by The Labour Relations Act. Loosening the legal constraints would permit greater flexibility in the determination of bargaining units, reduce the structural disparity between employees and employer, and enhance the prospects for fruitful bargaining. Compulsory first-agreement arbitration cannot do this. Even a liberal approach to the use of arbitration as a remedy for recognition disputes cannot redress a problem with structural roots. In 1944, Bora Laskin predicted that 'the battle for collective bargaining, for the opportunity of employees to share in the determination of the conditions under which they will work, is on the way to being won in Ontario' (Canadian Bar Review, 1944:783). But for workers in the service industries, the battle has just been engaged. For unions to be an effective countervailing power, bargaining structures must be reshaped.

\section{REFERENCES}

ADAMS, George, «Labour Board Remedies on Entering the 1980's», in Faculty of Law, McGill University, New Developments in Federal and Provincial Labour Laws, Montréal, 1981, pp. 153-179.

ADELL, Bernard, «The Duty to Bargain in Good Faith: Making Up for Lost Time», 28th Annual Conference, McGill Industrial Relations Centre, March 18, 1980.

ARMSTRONG, T.E., «The Duty to Bargain in Good Faith: Definition and Remedy», Canadian Business Review, vol. 3, no. 3, 1976, pp. 35-37.

BENDEL, Michael, «A Rational Process of Persuasion: Good Faith Bargaining in Ontario», University of Toronto Law Journal, vol. 30, 1980, pp. 1-45.

BROMKE, Adam, The Labour Relations Board in Ontario, The Industrial Relations Centre, McGill University, Montréal, 1961.

COX, Archibald, "The Duty to Bargain in Good Faith», Harvard Law Review, vol. 17 , no. 8, 1958, pp. 1401-1442.

DORSEY, James E., Canada Labour Relations Board, The Carswell Company Limited, 1983.

KORPESHO, J.M.P., «First Contract Experience in Manitoba», Paper presented to the Canadian Industrial Relations Association, 1986.

LASKIN, Bora, «Recent Labour Legislation in Canada», Canadian Bar Review, vol. 22, 1944, pp. 776-792.

ONTARIO LABOUR RELATIONS BOARD, Annual Report 1984-85.

SACK, Jeffrey and Martin LEVINSON, Ontario Labour Relations Board Practice, Toronto, Butterworths, 1973.

SACK, Jeffrey and C. Michael MITCHELL, Ontario Labour Relations Board Law and Practice, Toronto, Butterworths, 1985.

The Labour Relations Act, R.S.O. 1980, c. 228.

WEILER, Paul C., Reconcilable Differences, Toronto, The Carswell Company Limited, 1980. 